\title{
Studies on Biomass Yield, Morphological Characteristics and Nutritive Quality of Napier Cultivars under Two Different Geo-Topographic Conditions of Bangladesh
}

\author{
Nathu Ram Sarker*, Mohammed Ahsan Habib, Dilruba Yeasmin, Farah Tabassum, \\ Rurul Amin Mohammed
}

Fodder Research and Development Project, Bangladesh Livestock Research Institute, Dhaka, Bangladesh

Email: *sarkernr62@yahoo.com

How to cite this paper: Sarker, N.R., Habib, M.A., Yeasmin, D., Tabassum, F. and Mohammed, R.A. (2021) Studies on Biomass Yield, Morphological Characteristics and Nutritive Quality of Napier Cultivars under Two Different Geo-Topographic Conditions of Bangladesh. American Journal of Plant Sciences, 12, 914-925.

https://doi.org/10.4236/ajps.2021.126061

Received: May 10, 2021

Accepted: June 19, 2021

Published: June 22, 2021

Copyright $\odot 2021$ by author(s) and Scientific Research Publishing Inc. This work is licensed under the Creative Commons Attribution International License (CC BY 4.0).

http://creativecommons.org/licenses/by/4.0/

\begin{abstract}
The aim of the present study was to evaluate the performance of Napier cultivars in terms of forage yield, plant morphology and nutrient contents under two different agro-ecology and geo-topographic conditions. Three Napier cultivars being conserved by Bangladesh Livestock Research Institute (BLRI), namely-BLRI-Napier 1, (BN-1), BLRI-Napier 3 (BN-3) and Merkeron (BN-5) were selected to cultivate in severe drought prone areas (called Barind) and non-drought area at Savar (Modhupur terrace). Stem cuttings were planted in rows apart from $70 \mathrm{~cm}$ and $35 \mathrm{~cm}$ spacing between plants. Data of 6 consecutive harvests from a period of approximately one year were collected and analyzed statistically by " $R$ " software. The results showed that cultivar and location had a significant $(\mathrm{P}<0.001)$ effect on biomass yield, plant height and leaf-stem ratio (LSR), while number of tillers were significantly varied with locations. BN-3 yielded the highest biomass $(33.32 \mathrm{t} / \mathrm{ha} / \mathrm{harvest})$ at nondrought location (42.98 t/ha/harvest). The highest plant height was obtained in BN-1 $(171.2 \mathrm{~cm})$ at non-drought location $(174.6 \mathrm{~cm})$. Number of tillers per hill ranged from 25.4 to 26.3 among cultivars $(P>0.05)$ and the highest tillers were found at non-drought location $(28.1 \mathrm{no})$. The best LSR was estimated from $\mathrm{BN}-5(0.86)$ at drought location (0.95). The proximate analysis showed that $\mathrm{CP}, \mathrm{ADF}$ and $\mathrm{NDF}$ in whole plant were varied significantly $(\mathrm{P}<0.001)$, being the highest contents in $\mathrm{BN}-1$ (10.69\%, $46.20 \%$ and $54.58 \%$, respectively). On the other hand, DM and ash contents did not differ significantly ( $\mathrm{P}>$ 0.05 ) among cultivars which ranged from $15.80 \%$ to $17.13 \%$ and $13.10 \%$ to $14.58 \%$, respectively. The highest CP content in whole plant was obtained at non-drought location (11.89\%), while the lowest ash (10.57\%) and NDF
\end{abstract}


(52.71\%) contents were obtained at the same location. The highest CP contents in leaf were found at non-drought (15.03\%) and the lowest ash (9.86\%) at the same location. The highest CP contents (5.90\%) in stem were found at non-drought location, while the lowest ash (11.28\%) and NDF (54.59\%) contents were obtained at the same location. Finally, the experiment reveals the superiority in biomass yield and nutritional quality (in terms of $\mathrm{CP}$ content) with the ranking orders of $\mathrm{BN}-3>\mathrm{BN}-1>\mathrm{BN}-5$ and $\mathrm{BN}-1>\mathrm{BN}-3>\mathrm{BN}-5$. Therefore, it may be concluded that $\mathrm{BN}-1, \mathrm{BN}-3$, and $\mathrm{BN}-5$ cultivars were well adapted in both drought and non-drought conditions, although performance showed better in later conditions. However, in terms of forage yield and overall nutrient composition, the performance of $\mathrm{BN}-3$ was the best irrespective of locations.

\section{Keywords}

Napier Cultivars, Barind, Forage Yield, Plant Morphology, Nutrient Contents

\section{Introduction}

Napier grass (Pennisetum purpureum) is one of the most popular grasses in the tropics and sub-tropics and has been the most promising and high yielding fodder giving high nutritional characteristics and adaptability that suppresses most tropical grasses. Napier is a perennial grass grown massively as a fodder crop for cut-and-carry zero-grazing dairy systems [1] and constitutes up to $80 \%$ of forage for smallholder dairy farms [2]. Napier is the choice not only in the tropics but also worldwide due to its desirable traits such as tolerance to drought and a wide range of soil conditions, and high photosynthetic and water-use efficiency [3]. So far, lots of varieties of Napier or elephant grass have been developed worldwide. Bangladesh Livestock Research Institute (BLRI) is conserving several cultivars which need to be assessed in terms of yield and quality response cultivated in different geo-topography and agro-climatic conditions of Bangladesh.

Grasses in the tropics and subtropics grow rapidly during the period of much precipitation and high temperature. However, drought is being considered as the main cause of losses for agricultural as well as forage crop yields in northwestern regions of Bangladesh, which are particularly exposed to drought. The agricultural drought, linked to soil moisture scarcity, occurs at different stages of crop growth, development, and reproduction. Monsoon failure often brings famine to the affected regions and as a result crop production reduces drastically. According to [4] drought is the most devastating abiotic stress, which is caused by insufficient rainfall and/or altered precipitation patterns. In the context of agriculture, drought can be defined as the situation in which the amount of water available to the plant in the root zone is less than that required to sustain maximum growth and productivity [5]. The associated crop production decline, lower employment opportunities and losses of assets contributed to raise household 
food insecurity. Vegetables and several other pulses varieties are in short supply throughout the drought [6].

Apart from the agricultural losses, drought has an important effect on livestock production, land degradation, health, and employment. In drought prone areas, the scarcity of feeds and fodder is one of the most important problems in Bangladesh for rearing dairy cows. Therefore, drought tolerance high yielding Napier cultivars need to be identified and propagated to minimize scarcity of green grasses in the drought prone northwestern regions of Bangladesh. In that relation, this study was aimed with a view to compare three cultivars of Napier grass in terms of forage yields, plant morphology, and nutritional quality under drought and non-drought agro-climatic conditions of Bangladesh.

\section{Materials and Methods}

\subsection{Location and Duration of Experiment}

The study was conducted under four (4) Upazilas' (sub-districts) having two severe drought-prone districts in the northwestern part of Bangladesh (Rajshahi and Chapai-Nawabganj). Severe drought prone Barind tract (called Barendra land or "Barind") area included Nachol, Gomostapur and Sadar Upazilas under Chapai Nawabganj district and Godagari Upazila in Rajshahi district and nondrought area at Savar Upazila belongs to Dhaka district. The experiment was conducted for a period of a calendar year started from July 2016 to June 2017.

\subsection{Geo-Topography of the Locations}

The study areas of Chapai Nawabganj and the big city Rajshahi are very close to each other and the climate of both districts are very similar. Geographically, the study areas extend from $24^{\circ} 22^{\prime} \mathrm{N}$ to $24^{\circ} 73^{\prime} \mathrm{N}$ latitude and from $88^{\circ} 36^{\prime} \mathrm{E}$ to $88^{\circ} 20^{\prime} \mathrm{E}$ longitude. The topography of this area is mainly flat with an average elevation of $25 \mathrm{~m}$ above mean sea level. Though, there are many small ponds and water reservoirs in Chapai Nawabganj, but recently, the geography has changed due to the erosion by the river Padma (Ganges). Overload of river sediment caused by "Farrakka barrage" eroded the river banks and created a large area of land full of sand which almost looks like a small desert in this area. The surface geology in a major part of the area is composed of uplifted terraces of Pleistocene sediments called Barind Tracts, which are more strongly weathered than the surrounding alluvium. The east part of the river Mohananda is part of "Borind Tract" and is known as borendra area. Chapai Nawabganj Sadar, part of Gomostapur Upozilla and Nachol constitutes the borendra area. The main crops of this area are rice (Source: https://en.wikipedia.org/wiki/Chapai_Nawabganj_District). Climatically, the area is in a dry humid zone with annual average rainfall varying between 1400 and $1650 \mathrm{~mm}$, among which almost 83\% rainfall occurs during monsoon (June-October). The hot season commences early in March and continues till the middle of July. The maximum mean temperature observed is about $25^{\circ} \mathrm{C}$ to $35^{\circ} \mathrm{C}$ during the months of April, May, June and July and the minimum temper- 
ature recorded in January is about $7^{\circ} \mathrm{C}$ to $16^{\circ} \mathrm{C}$ [7].

On the other hand, the experimental site of non-drought location (Pachutia fodder research farm at Bangladesh Livestock Research Institute, Savar, Dhaka) is geographically located at $24^{\circ} 42^{\prime} 0^{\prime \prime} \mathrm{N}$ latitude and $90^{\circ} 22^{\prime} 30^{\prime \prime} \mathrm{E}$ longitude and at an altitude of 4 meters above the sea level. The soil of that site is clayed in texture and the climate is classified as tropical. According to meteorological data taken in Savar Upazila (near the study site), the mean maximum temperature of $28.9^{\circ} \mathrm{C}$ is recorded in May, which is the hottest month of the year and the mean lowest temperature of $18.8^{\circ} \mathrm{C}$ is recorded in January, which is the coldest month of the year. The maximum temperature of $34.4^{\circ} \mathrm{C}$ is recorded in April and lowest of $12.1^{\circ} \mathrm{C}$ in January. The total annual rainfall is $1990 \mathrm{~mm}$ and shows a unimodal distribution pattern, with the main precipitation from May to September. Precipitation is the lowest in December, with an average of $6 \mathrm{~mm}$. Most precipitation falls in July, with an average of $372 \mathrm{~mm}$. The mean relative humidity ranged from $54 \%$ to $83 \%$ (Source:

https://en.climate-data.org/asia/bangladesh/dhaka-division/savar-123710/).

\subsection{Description of Napier Cultivars}

The BN-1 is the Bajra Napier grass, which is the product of hybridization between bajra (Pennisetum glaucum) and Elephant grass (Pennisetum purpurium), characterized by perennial and deep rooting in nature having good palatability and taste. The BN-3 was developed by accession selection Napier hybrid, which is the product of interspecific crosses between common elephant grass (Pennisetum purpureum) and pearl millet (Pennisetum glaucum). It is characterized by moderate height with profuse tillers and better leaves to stem ratio. It has very few barbs in leafs and stems which are not harmful to human skin. The flowering stage of this grass comes into delay and can be first harvested to 50 - 60 days after plantation with 40 - 45 days subsequent harvests. The BN-5 is a dwarf cultivar of Napier grass (Pennisetum purpurium Schumach) known as "Merkeron" was first released by the University of Georgia in 1889 with improved yield potential and disease resistance. It is characterized by a late-heading type with leafy and of high feed value.

The Napier varieties can be cultivated on various soil but give the best result when grown on heavy soils having high nutrient fertility. All those are tolerant to mild salinity and avoid water logged condition. Seeds are very small so for commercial planting those are propagated by stem cuttings (having two-three nodes) or root slips (approximately $30 \mathrm{~cm}$ long). Napier varieties contain 7\% $10 \%$ crude protein, $28 \%-30 \%$ crude fibre and $10 \%-11.5 \%$ ash on dry matter basis. Once planted, those can give 8 - 10 harvests in a year and provide foliage yield for up to 5 - 6 years, if can be managed properly.

\subsection{Land Preparation and Cultivation}

In each location, 5 plots (with an area of $25 \mathrm{~m}^{2}$ ) for each cultivar were well prepared by weed slashing, ploughed, laddering and application of manure. Farm 
yard manure (FYM), urea, triple super phosphate (TSP) and muriate of potash (MP)@ $20 \mathrm{MT}, 60 \mathrm{~kg}, 70 \mathrm{~kg} / \mathrm{ha}$ and $30 \mathrm{~kg} / \mathrm{ha}$, respectively, were applied before ploughing. After land preparation, stem cuttings (including 2 nodes) were transplanted in rows apart from $70 \mathrm{~cm}$ with $35 \mathrm{~cm}$ spacing between plants. After 30 days of plantation, first weeding followed by top dressing with urea @ $60 \mathrm{~kg} / \mathrm{ha}$ along with adequate irrigation was applied.

\subsection{Harvesting and Yield Measurement}

At the stipulated time of harvest, plants within one square meter area from five places of each plot were cut about $5 \mathrm{~cm}$ above the ground level and weighed for green biomass yields and converted production to metric ton per hectare of land. For plant height measurement, the tallest tillers of randomly selected 5 hills in each plot were taken and measured in $\mathrm{cm}$ from above the ground level to apex of the tiller. Leaves and stems of randomly selected 5 plants from each of the plot were separated and weighed individually in grams. Weights of leaves were divided by weight of stem to estimate leaf to stem ratio (LSR). There were a total six harvests obtained in a year and all the measurements were averaged to estimate single harvest basis.

\subsection{Proximate Analysis}

For analysis of proximate components, the specimen of different botanical fractions (leaf, stem and whole plant) of three cultivars taken from different harvests and locations were analyzed in the laboratory by using the method of [8] for determination of DM, CP and Ash. On the other hand, ADF and NDF were determined through using the methods developed by [9]. All the samples were analyzed in duplicates (as replicate samples) and mean values were recorded.

\subsection{Experimental Design and Analysis}

In our experiment, a $2 \times 3$ factorial ANOVA including two locations and three cultivars was employed to test the overall fixed effects and interactions between effects with the following general linear model:

$$
Y_{i j k}=\mu+C_{i}+L_{j}+(C L)_{i j}+e_{i j k},
$$

where $\mu=$ overall mean, $C_{i}=$ effects of the $i^{\text {th }}$ cultivar, $L_{j}=$ effects of $j^{\text {th }}$ location, $(C L)_{i j}=$ effect of interaction between $i^{\text {th }}$ cultivar and $f^{\text {th }}$ location and $e_{i j k}=$ error term. The Tukey's HSD post hoc test was used for pairwise comparison between means. The means were considered to be statistically significant when P-value was less than 5\% $(\mathrm{P}<0.05)$. The means along with standard error of the means for forage yields, plant morphology and nutrient contents were computed using [10] "R" software with Agricolae and Pastecs packages.

\section{Results and Discussion}

Table 1 illustrated the yield and plant morphology of Napier cultivars as affected 
Table 1. Effect of cultivar and location on biomass yield and plant morphology.

\begin{tabular}{ccccc}
\hline \multirow{2}{*}{ Fixed effect } & \multicolumn{4}{c}{ Yield and plant morphology character } \\
\cline { 2 - 5 } & $\begin{array}{c}\text { Biomass yield } \\
(\mathrm{t} / \mathrm{ha} / \text { harvest })\end{array}$ & $\begin{array}{c}\text { Plant height } \\
(\mathrm{cm})\end{array}$ & $\begin{array}{c}\text { Tiller per clump } \\
(\mathrm{no})\end{array}$ & $\begin{array}{c}\text { Leaf-stem ratio } \\
(\text { LSR })\end{array}$ \\
\hline Cultivar (C) & $30.72^{\mathrm{b}}$ & $171.2^{\mathrm{a}}$ & 25.9 & $0.73^{\mathrm{b}}$ \\
BN-1 & $33.32^{\mathrm{a}}$ & $157.9^{\mathrm{b}}$ & 26.3 & $0.85^{\mathrm{a}}$ \\
BN-3 & $29.00^{\mathrm{b}}$ & $156.3^{\mathrm{b}}$ & 25.4 & $0.86^{\mathrm{a}}$ \\
BN-5 & $1.64 \mathrm{e}-04^{* * *}$ & $<0.2 \mathrm{e}-16^{* * *}$ & $0.308 \mathrm{NS}$ & $6.53 \mathrm{e}-06^{* * *}$ \\
P-value (C) & & $136.5^{\mathrm{b}}$ & $21.3^{\mathrm{b}}$ & $0.95^{\mathrm{a}}$ \\
Location (L) & $23.25^{\mathrm{b}}$ & $174.6^{\mathrm{a}}$ & $28.1^{\mathrm{a}}$ & $0.70^{\mathrm{b}}$ \\
Drought & $42.98^{\mathrm{a}}$ & $<0.2 \mathrm{e}-16^{* * *}$ & $<2 \mathrm{e}-16^{* * *}$ & $<2 \mathrm{e}-16^{* * *}$ \\
Non-drought & $<2 \mathrm{e}-16^{* * *}$ & $4.73 \mathrm{e}-07^{* * *}$ & $0.217^{\mathrm{NS}}$ & $0.81^{\mathrm{NS}}$ \\
P-value (L) & $6.19 \mathrm{e}-04^{* * *}$ & 161.8 & 25.8 & 0.81 \\
P-value (C $\times \mathrm{L})$ & 31.03 & 0.81 & 0.26 & 0.01 \\
Overall mean & 0.54 & & & \\
SEM & & & & \\
\hline
\end{tabular}

SEM = standard error of mean; $\mathrm{C} \times \mathrm{L}=$ interaction between cultivar and location; ${ }^{* * *}=$ significant at $0.1 \%$ level $(\mathrm{P}<0.001)$; NS = not significant at $5 \%$ level $(\mathrm{P}>0.05)$; means with different superscript within same column differ significantly $(\mathrm{P}<0.05)$.

by cultivar and location. Statistical analysis showed that cultivar and location had a highly significant $(\mathrm{P}<0.001)$ effect on biomass yield. Irrespective of location, the highest biomass yield was obtained from BN-3 (33.32 t/ha/harvest). On the other hand, irrespective of cultivar, the highest biomass yield was obtained at non-drought location (42.98 t/ha/harvest) as compared to drought location. Both fixed effects, the least squares mean of biomass yield was $31.03 \mathrm{t} / \mathrm{ha} / \mathrm{harvest}$. According to [11] studied comparative performance of 8 hybrid Napier cultivars and obtained the highest green yields of $52.67 \mathrm{t} / \mathrm{ha}$ which was higher than this study. Further [11] also investigated significant variations among cultivars with respect to green fodder yields recorded at six harvests.

In another study, [12] studied 8 cultivars of Napier grass in Thailand and found significant difference in annual biomass yield among cultivars. Their studies confirmed our present study. Actually, plant biomass yield is associated with number of factors like plant height, number of tiller, leafiness (measured by leaf number and leaf area per plant) etc. Higher biomass production in $\mathrm{BN}-3$ could be due to the factors mentioned earlier.

As shown in Table 1, cultivar and location had highly significant $(\mathrm{P}<0.001)$ effects on plant height. The highest plant height was observed in BN-1 (171.2 $\mathrm{cm}$ ), irrespective of location. On the other hand, regardless of cultivar, the highest plant height was investigated at non-drought location $(174.6 \mathrm{~cm})$ as compared to drought location. Considering both effects, the least squares mean of plant height was $161.8 \mathrm{~cm}$. In a recent study, [13] reported stem height of four Napier cultivars ranged from 145.44 to $210.81 \mathrm{~cm}$ with significant variations 
among them which conforms to our study. The number of tillers per hill did not differ significantly $(P>0.05)$ among cultivars, while tillers, as obtained at non-drought location $(28.1 \mathrm{no} / \mathrm{hill})$, was significantly $(\mathrm{P}<0.001)$ higher than that obtained at drought location. The effect of cultivar on tillers in our study was not agreed with who [13] while agreed on the effect of location. Considering both fixed effects, the least squares mean of number of tillers per hill was 25.8, which is in general agreement with [13] who reported 9.96 to 28.87 numbers per hill of four Napier cultivars. Leaves to stem ratio (LSR) differed significantly (P < 0.001 ) for the direct effects of cultivar and location. Similar effects were also investigated by [11] [13] and their studies revealed the variations of LSR in different cultivars are due to characteristics of stem and leaves. Some varieties are characterized by thin stem and numerous leaves and some are thick stem with fewer leaves. Regardless of location, the highest LSR was obtained in BN-3 (0.86) and at drought location (0.95) regardless of cultivar. Considering both fixed effects, the least squares mean of LSR was 0.81 , which is in the line of the study of [11] who reported average leaf: stem ranged from 0.66 to 0.92 in 8 hybrid Napier cultivars. The variations of forage yield and plant morphology between locations could be due to the difference of environmental factors like rainfall, temperature, humidity, soil condition, agronomical management, etc. Earlier, [14] [15] reported forage crops to be highly area and location-specific. The soil condition in the drought areas is not suitable for yields of many crops due to lack of moisture caused by acute shortage of rainfall. [16] also reported that Napier is highly productive in areas with good soil fertility and high rainfall, growing well up to 2000 masl. This could be the main reason for production fall of Napier cultivars in drought location as compared to non-drought location. Analysis of variance also revealed highly significant $(\mathrm{P}<0.001)$ interaction effect between cultivar and location for forage yield and plant height, which implies that all cultivars did not behave similar in both locations.

The proximate components in whole plant, leaves and stem as affected by cultivar and location are depicted in Tables 2-4. The dry matter (DM) contents in whole plant and leaves were not found to vary for the direct effect of cultivar, while it varied significantly $(\mathrm{P}<0.05)$ for stem. On the other hand, location had no significant $(\mathrm{P}>0.05)$ effect on DM contents in all botanical fraction of Napier cultivars. Regardless of cultivar and location, the least squares mean of DM in whole plant, leaf and stem were $16.66 \%, 22.74 \%$ and $12.66 \%$, respectively. [13] reported leaf, stem and total DM contents in four varieties of Napier to be ranged from $17.44 \%$ to $22.87 \%, 8.29 \%$ to $14.7 \%$ and $12.87 \%$ to $18.78 \%$, respectively which are in accordance with our investigation. DM content largely depends on plant maturity and moisture in soil. The importance of soil moisture to plant growth was high-lighted by the marked reduction of dry matter yields

The crude protein $(\mathrm{CP})$ contents in whole plant and stem were found to have significant $(\mathrm{P}<0.001 ; \mathrm{P}<0.01)$ variation for the effect of cultivar, while it was not varied significantly $(\mathrm{P}>0.05)$ in leaf. The highest $\mathrm{CP}$ contents in whole plant (10.69\%) and stem (6.21\%) were obtained in $\mathrm{BN}-1$ and $\mathrm{BN}-3$, respectively. On 
Table 2. Effect of cultivar and location on nutrient contents in whole plant of three Napier cultivars.

\begin{tabular}{cccccc}
\hline \multirow{2}{*}{ Fixed effect } & \multicolumn{5}{c}{ Nutrient contents in whole plant } \\
\cline { 2 - 6 } & DM (\%) & CP (\%) & Ash (\%) & ADF (\%) & NDF (\%) \\
\hline Cultivar (C) & & & & \\
BN-1 & 16.94 & $10.69^{\mathrm{a}}$ & 14.58 & $46.20^{\mathrm{a}}$ & $54.98^{\mathrm{a}}$ \\
BN-3 & 17.13 & $9.80^{\mathrm{b}}$ & 13.69 & $41.07^{\mathrm{c}}$ & $51.66^{\mathrm{c}}$ \\
BN-5 & 15.80 & $9.30^{\mathrm{b}}$ & 13.10 & $44.12^{\mathrm{b}}$ & $52.86^{\mathrm{b}}$ \\
P-value (C) & $0.208^{\mathrm{NS}}$ & $1.08 \mathrm{e}-04^{* * *}$ & $0.102^{\mathrm{NS}}$ & $<2 \mathrm{e}-16^{* * *}$ & $<2 \mathrm{e}-16^{* * *}$ \\
Location (L) & & & & & \\
Drought & 16.86 & $9.55^{\mathrm{b}}$ & $14.49^{\mathrm{a}}$ & 43.83 & $53.27^{\mathrm{a}}$ \\
Non-drought & 15.67 & $11.89^{\mathrm{a}}$ & $10.57^{\mathrm{b}}$ & 43.45 & $52.71^{\mathrm{b}}$ \\
P-value (L) & $0.132^{\mathrm{NS}}$ & $3.65 \mathrm{e}-10^{* * *}$ & $6.52 \mathrm{e}-08^{* * *}$ & $0.171^{\mathrm{NS}}$ & $0.0372^{*}$ \\
P-value (C $\times \mathrm{L})$ & $0.397^{\mathrm{NS}}$ & $0.388^{\mathrm{NS}}$ & $0.639^{\mathrm{NS}}$ & $0.915^{\mathrm{NS}}$ & $0.939^{\mathrm{NS}}$ \\
Overall mean & 16.66 & 9.96 & 13.81 & 43.77 & 53.17 \\
SEM & 0.32 & 0.15 & 0.30 & 0.23 & 0.17 \\
\hline
\end{tabular}

SEM = standard error of mean; $\mathrm{C} \times \mathrm{L}=$ interaction between cultivar and location; ${ }^{\star}=$ significant at $5 \%$ level $(\mathrm{P}<0.05) ;{ }^{* *}=$ significant at $0.1 \%$ level $(\mathrm{P}<0.001)$; $\mathrm{NS}=$ not significant at $5 \%$ level $(\mathrm{P}>0.05)$; means with different superscript within same column differ significantly $(\mathrm{P}<0.05)$.

Table 3. Effect of cultivar and location on nutrient contents in leaf of three Napier cultivars.

\begin{tabular}{|c|c|c|c|c|c|}
\hline \multirow{2}{*}{ Fixed effect } & \multicolumn{5}{|c|}{ Nutrient contents in leaf } \\
\hline & $\mathrm{DM}(\%)$ & $\mathrm{CP}(\%)$ & Ash (\%) & $\operatorname{ADF}(\%)$ & NDF (\%) \\
\hline \multicolumn{6}{|l|}{ Cultivar (C) } \\
\hline $\mathrm{BN}-1$ & 23.15 & 12.53 & 13.21 & $44.71^{\mathrm{a}}$ & $53.24^{\mathrm{a}}$ \\
\hline $\mathrm{BN}-3$ & 22.87 & 12.24 & 12.59 & $40.26^{\mathrm{c}}$ & $48.96^{\mathrm{c}}$ \\
\hline BN-5 & 22.10 & 11.98 & 12.13 & $41.96^{\mathrm{b}}$ & $51.08^{\mathrm{b}}$ \\
\hline P-value $(\mathrm{C})$ & $0.351^{\mathrm{NS}}$ & $0.343^{\mathrm{NS}}$ & $0.123^{\mathrm{NS}}$ & $2.19 \mathrm{e}-14^{\star * *}$ & $<2 \mathrm{e}-16^{* * *}$ \\
\hline \multicolumn{6}{|l|}{ Location (L) } \\
\hline Drought & 22.58 & $11.67^{\mathrm{b}}$ & $13.25^{\mathrm{a}}$ & 42.35 & 51.15 \\
\hline Non-drought & 23.50 & $15.03^{\mathrm{a}}$ & $9.86^{\mathrm{b}}$ & 42.11 & 50.78 \\
\hline P-value (L) & $0.305^{\mathrm{NS}}$ & $1.21 \mathrm{e}-14^{\star * *}$ & $1.37 \mathrm{e}-09^{\star \star \star}$ & $0.414^{\mathrm{NS}}$ & $0.114^{\mathrm{NS}}$ \\
\hline $\mathrm{P}$-value $(\mathrm{C} \times \mathrm{L})$ & $0.349^{\mathrm{NS}}$ & $0.157^{\mathrm{NS}}$ & $0.550^{\mathrm{NS}}$ & $0.989^{\mathrm{NS}}$ & $0.980^{\mathrm{NS}}$ \\
\hline Overall mean & 22.74 & 12.26 & 12.67 & 42.31 & 51.08 \\
\hline SEM & 0.30 & 0.18 & 0.23 & 0.26 & 0.18 \\
\hline
\end{tabular}

SEM = standard error of mean; $\mathrm{C} \times \mathrm{L}=$ interaction between cultivar and location; ${ }^{* * *}=$ significant at $0.1 \%$ level $(\mathrm{P}<0.001)$; NS = not significant at $5 \%$ level $(\mathrm{P}>0.05)$; means with different superscript within same column differ significantly $(\mathrm{P}<0.05)$. 
Table 4. Effect of cultivar and location on nutrient contents in stem of three Napier cultivars.

\begin{tabular}{cccccc}
\hline \multirow{2}{*}{ Fixed effect } & \multicolumn{5}{c}{ Nutrient contents in stem } \\
\cline { 2 - 6 } & DM (\%) & CP (\%) & Ash (\%) & ADF (\%) & NDF (\%) \\
\hline Cultivar (C) & & & & \\
BN-1 & $13.53^{\mathrm{a}}$ & $5.86^{\mathrm{ab}}$ & 15.23 & $48.36^{\mathrm{a}}$ & $56.58^{\mathrm{a}}$ \\
BN-3 & $11.78^{\mathrm{b}}$ & $6.21^{\mathrm{a}}$ & 14.22 & $42.78^{\mathrm{c}}$ & $54.44^{\mathrm{b}}$ \\
BN-5 & $12.69^{\mathrm{ab}}$ & $5.56^{\mathrm{b}}$ & 14.12 & $45.96^{\mathrm{b}}$ & $54.79^{\mathrm{b}}$ \\
P-value (C) & $0.0222^{*}$ & $4.85 \mathrm{e}^{\mathrm{b}}-03^{* *}$ & $0.234^{\mathrm{NS}}$ & $2.8 \mathrm{e}-15^{* * *}$ & $2.47 \mathrm{e}^{*}-06^{* * *}$ \\
Location (L) & & & & & \\
Drought & 13.24 & $5.68^{\mathrm{b}}$ & $15.22^{\mathrm{a}}$ & 45.74 & $55.44^{\mathrm{a}}$ \\
Non-drought & 12.54 & $5.90^{\mathrm{a}}$ & $11.28^{\mathrm{b}}$ & 45.36 & $54.59^{\mathrm{b}}$ \\
P-value (L) & $0.476^{\mathrm{NS}}$ & $1.97 \mathrm{e}-08^{* * *}$ & $2.92 \mathrm{e}-07^{* * *}$ & $0.371^{\mathrm{NS}}$ & $0.0423^{*}$ \\
P-value (C $\times \mathrm{L})$ & $0.959^{\mathrm{NS}}$ & $0.274^{\mathrm{NS}}$ & $0.832^{\mathrm{NS}}$ & $1.00^{\mathrm{NS}}$ & $0.990^{\mathrm{NS}}$ \\
Overall mean & 12.66 & 5.89 & 14.54 & 45.67 & 55.29 \\
SEM & 0.26 & 0.08 & 0.31 & 0.31 & 0.19 \\
\hline
\end{tabular}

SEM = standard error of mean; $\mathrm{C} \times \mathrm{L}=$ interaction between cultivar and location; ${ }^{\star}=$ significant at $5 \%$ level $(\mathrm{P}<0.05) ;{ }^{* *}=$ significant at $1 \%$ level $(\mathrm{P}<0.01) ;{ }^{* *}=$ significant at $0.1 \%$ level $(\mathrm{P}<0.001)$; NS = not significant at 5\% level $(\mathrm{P}>0.05)$; means with different superscript within same column differ significantly $(\mathrm{P}<$ $0.05)$.

the other hand, location had highly significant $(\mathrm{P}<0.001)$ effect on $\mathrm{CP}$ contents in all botanical fractions. Highest CP contents in all botanical fractions were estimated at non-drought location. Regardless of cultivar and location, the least squares mean of CP contents in whole plant, leaf and stem were $9.96 \%, 12.26 \%$ and 5.89\%, respectively. According to [17] Napier hybrid in general contains about $10.2 \%$ CP, which closely agrees with our study. In another study, [18] reported CP contents in 3 Napier hybrid cultivars to be $16.5 \%$ to $17.2 \%$ in leaf, $3.6 \%$ to $5.6 \%$ in stem and $10.4 \%$ to $11.2 \%$ in whole plant, which closely agrees with this study, except that of CP content in leaf. Earlier, [11] reported CP contents in different hybrid Napier which ranged from $11.23 \%$ to $13.83 \%$ in leaf and $6.14 \%$ to $8.4 \%$ in stem which are in general agreement with our findings.

The ash contents in all botanical fractions of plant were found to have no significant $(\mathrm{P}>0.05)$ effects for cultivar, while those varied significantly $(\mathrm{P}<0.001)$ for the direct effect of location. Similar effects had been claimed by Maleko [13] in their experiment. In all botanical fractions, the highest ash contents were obtained at drought location. Regardless of cultivar and location, the least squares mean of ash contents in whole plant, leaf and stem were $13.81 \%, 12.67 \%$ and $14.54 \%$, respectively. [12] reported ash concentration to be $10.9 \%$ to $15.9 \%$ in Napier harvested in dry seasons. Earlier, [11] reported ash contents in different hybrid Napier cultivars which ranged from $11.62 \%$ to $13.07 \%$ in leaves and $12.30 \%$ to $13.90 \%$ in stem. Our findings fall within the range of their reports. In contrast, [13] reported comparatively lower estimates of ash contents in four va- 
rieties of Napier cultivar ranged from $7.96 \%$ to $9.38 \%$. Plant physiologic or agroclimatic factors could be the reason of variations between works. Forage mineral and ash contents were reported to be influenced by edaphic factors, seasons and biomass dry matter proportion [19].

The acid detergent fiber $(\mathrm{ADF})$ contents in all botanical fractions were found to have highly significant $(\mathrm{P}<0.001)$ effects for cultivar. The lowest ADF contents in all botanical fractions were found in $\mathrm{BN}-3$. On the other hand, location had no significant $(\mathrm{P}>0.05)$ effect on ADF contents in all botanical fractions, which agrees well with [13]. Regardless of cultivar and location, the least squares mean of ADF contents in whole plant, leaf and stem were $43.77 \%, 42.31 \%$ and $45.67 \%$, respectively. Recently, [13] reported ADF contents ranged from $35.83 \%$ to $39.40 \%$ in four varieties of Napier. Earlier, [20] obtained $39.57 \%$ ADF in hybrid Napier cultivar $\left(\mathrm{CO}_{3}\right)$ at green stage. Their reports are somewhat lower than our study, which could be due to variation of DM content or duration of harvest between works or may be other factors like properties of cultivar, soil, climate, analytical methods followed in the laboratory, cutting interval, etc.

The neutral detergent fiber (NDF) contents in whole plant, leaf and stem differed significantly $(\mathrm{P}<0.001)$ for the direct effect of cultivar. The lowest NDF contents in all botanical fractions were found in BN-3. On the other hand, location had significant $(\mathrm{P}<0.05)$ effect on ADF contents in whole plant and stem, being lowest at non-drought location, while ADF content in leaf was not varied significantly $(\mathrm{P}>0.05)$. Conversely, [13] did not find any significant effect of variety and location on NDF content. Regardless of cultivar and location, the least squares mean of ADF contents in the whole plant, leaf and stem were $53.17 \%$, $51.08 \%$ and 55.29\%, respectively. Our estimates are lower than [13] who reported $62.93 \%$ to $66.63 \%$ NDF in different varieties of Napier. Earlier, [20] obtained $64.38 \%$ NDF in their study which is higher than present study. However, NDF values as found in our study followed within the range of $45 \%-65 \%$ which is regarded as roughage feed of moderate quality [21]. The variations of NDF among works could be due to different factors stated earlier.

The variations of nutrient contents in different works could be due to differences for variety or cultivar, stage of maturity or harvest, climate, cutting intervals, environment, soil fertility, or agronomical management practiced by different experiments. [11] reported to have wide differences of nutritive values among different Napier cultivars. The difference of nutrient contents due to the effect of location could be due to variations of agro-topography, soil texture and fertility.

This study confirmed that BN-1, BN-3 and BN-5 cultivars were well adapted in both drought and non-drought conditions, although performance showed better in later condition. However, in terms of forage yield and overall nutrient composition, BN-3 was the best one. Nevertheless, the effects of interactions between cultivar and location on forage yield and plant height were statistically significant, which implies that similar outcomes from three varieties cannot be expected in both locations. 


\section{Acknowledgements}

The authors are thankful to the Ministry of Fisheries and Livestock, Government of Bangladesh, for financial support through "Fodder Research and Development Project" implemented by Bangladesh Livestock Research Institute, Savar, Dhaka1341, Bangladesh.

\section{Conflicts of Interest}

The authors declare no conflicts of interest regarding the publication of this paper.

\section{References}

[1] Bayer, W. (1990) Napier Grass-A Promising Fodder for Smallholder Livestock Production in the Tropics. Plant Research for Development, 31, 103-111.

[2] Staal, S., Chege, L., Kenyanjui, M., Kimari, A., Lukuyu, B., Njubi, D., Owango, M., Tanner, J., Thorpe, W. and Wambugu, M. (1987) A Cross Sectional Survey of Kiambu District for the Identification of Target Groups of Smallholder Dairy Producers. KARI/ILRI Collaborative Project Research Report, Nairobi, Kenya.

[3] Anderson, W.F, Dien, B.S, Brandon, S.K. and Peterson, J.D. (2008) Assessment of Bermuda Grass and Bunch Grasses as Feed Stocks for Conversion to Ethanol. Applied Biochemistry and Biotechnology, 145, 13-21. https://doi.org/10.1007/s12010-007-8041-y

[4] Toker, C., Canci, H. and Yildirim, T. (2007) Evaluation of Perennial Wild Cicer Species for Drought Resistance. Genetic Resources and Crop Evolution, 54, 1781 1786. https://doi.org/10.1007/s10722-006-9197-y

[5] Deikman, J., Petracek, M. and Heard, J.E. (2012). Drought Tolerance through Biotechnology: Improving Translation from the Laboratory to Farmers' Fields. Current Opinion in Biotechnology, 23, 243-250. https://doi.org/10.1016/j.copbio.2011.11.003

[6] Dey, N.C., Alam, M.S., Sajjan, A.K., Bhuiyan, M.A., Ghose, L., Ibaraki, Y. and Karim, F. (2011). Assessing Environmental and Health Impact of Drought in the Northwest. Journal of Environmental Science and Natural Resources, 4, 89-97. https://doi.org/10.3329/jesnr.v4i2.10141

[7] Habiba, U., Shaw, R. and Yukiko Takeuchi, Y. (2011) Drought Risk Reduction through a Socio-Economic, Institutional and Physical Approach in the Northwestern Region of Bangladesh. Environmental Hazards, 10, 121-138. https://doi.org/10.1080/17477891.2011.582311

[8] AOAC (2005) Official Methods of Analysis of the Association of Official Analytical Chemists. 21st Edition, AOAC, Washington DC.

[9] Van Soest, P., Robertson, J. and Lewis, B. (1991) Methods for Dietary Fiber, NeutralDetergent Fiber and Non-Starch Polysaccharides in Relation to Animal Nutrition. Journal of Dairy Science, 74, 3583-3597. https://doi.org/10.3168/jds.S0022-0302(91)78551-2

[10] RStudio Team (2020) RStudio: Integrated Development for R. RStudio. MA URL, PBC, Boston. http://www.rstudio.com/

[11] Soumya, P. (2011) Evaluation of Promising Hybrid Napier Cultivars under Varying Plant Population. M.Sc. Thesis, Faculty of Agriculture, Kerala Agricultural Univer- 
sity, Thrissur, $73 \mathrm{p}$.

[12] Rengsirikul, K., Ishii, Y., Kangvansaichol, K., Sripichitt, P., Punsuvon, V., Vaithanomsat, P., Nakamanee, G. and Tudsril, S. (2013) Biomass Yield, Chemical Composition and Potential Ethanol Yields of 8 Cultivars of Napiergrass (Pennisetum purpureum Schumach) Harvested 3-Monthly in Central Thailand. Journal of Sustainable Bioenergy Systems, 3, 107-112. https://doi.org/10.4236/jsbs.2013.32015

[13] Maleko, D., Mwilawa, A., Msalya, G., Pasape, L. and Mtei, K. (2019) Forage Growth, Yield and Nutritional Characteristics of Four Varieties of Napier Grass (Pennisetum purpureum Schumach) in the West Usambara Highlands, Tanzania. Scientific African, 6, e00214. https://doi.org/10.1016/j.sciaf.2019.e00214

[14] Tessema, Z.K., Mihret, J. and Solomon, M. (2010) Effect of Defo-Liation Frequency and Cutting Height on Growth, Dry-Matter Yield and Nutritive Value of Napier Grass (Pennisetum purpureum (L.) Schumach). Grass and Forage Science, 65, 421430. https://doi.org/10.1111/j.1365-2494.2010.00761.x

[15] Pandey, K.C. and Roy, A.K. (2011) Forage Crops Varieties. Indian Grassland and Fodder Research Institute (IGFRI), Jhansi, India.

[16] Kumar, V. (2013) Napier Grass (Elephant Grass) Variety. http://goo.gl/tYvmea

[17] Thomas, C.G. (2008) Forage Crop Production in the Tropics. 2nd Editon, Kalyani Publishers, New Delhi, 333 p.

[18] Wangchuk, K., Rai, K., Nirola, H., Thukten Dendup, C. and Mongar, D. (2015) Forage Growth, Yield and Quality Responses of Napier Hybrid Grass Cultivars to Three Cutting Intervals in Himalayan Foothills. Tropical Grasslands, 3, 142-150. https://doi.org/10.17138/TGFT(3)142-150

[19] Mtengeti, E.J., Phiri, E.C.J.H., Urio, N.A., Mhando, D.G., Mvena, Z., Ryoba, R. and Lørken, T. (2008) Forage Availability and Its Quality in the Dry Season on Smallholder Dairy Farms in Tanzania. Acta Agriculturae Scandinavica, Section AAnimal Science, 58, 196-204. https://doi.org/10.1080/09064700802492362

[20] Elanchezhian, N. and Reddy, D.V. (2009) Nutritional Evaluation of $\mathrm{CO}_{3}$ Grass in Goats. Indian Journal of Animal Sciences, 79, 252-253.

[21] Turano, B., Tiwari, U.P. and Jha, R. (2016) Growth and Nutritional Evaluation of Napier Grass Hybrids as Forage for Ruminants. Tropical Grasslands-Forrajes Tropicales, 4, 168-178. https://doi.org/10.17138/TGFT(4)168-178 